\title{
Correction to: High fascin-1 expression in colorectal cancer identifies patients at high risk for early disease recurrence and associated mortality
}

\author{
Athanasios Tampakis ${ }^{1,2^{*}{ }^{\dagger}}$, Ekaterini-Christina Tampaki ${ }^{2 \dagger}$, Afrodite Nonni ${ }^{3}$, loannis D. Kostakis ${ }^{2}$, Alberto Posabella ${ }^{1}$, \\ Konstantinos Kontzoglou ${ }^{2}$, Markus von Flüe ${ }^{1}$, Evangelos Felekouras ${ }^{4}$, Gregory Kouraklis ${ }^{2}$ and Nikolaos Nikiteas ${ }^{2}$
}

\section{Correction to: BMC Cancer 21, 153 (2021) \\ https://doi.org/10.1186/s12885-021-07842-4}

Following publication of the original article [1], the authors identified an error in the author names. The given names and family names were erroneously transposed.

The correct author names are as follows:

Athanasios (given name) Tampakis (family name)

Ekaterini-Christina (given name) Tampaki (family name)

Afrodite (given name) Nonni (family name)

Ioannis D. (given name) Kostakis (family name)

Alberto (given name) Posabella (family name)

Konstantinos (given name) Kontzoglou (family name)

Markus (given name) von Flüe (family name)

Evangelos (given name) Felekouras (family name)

Gregory (given name) Kouraklis (family name)

Nikolaos (given name) Nikiteas (family name)

The author group has been updated above and the original article [1] has been corrected.

\begin{abstract}
Author details
${ }^{1}$ Clarunis, University Center for Gastrointestinal and Liver Disorders, University Hospital of Basel, Spitalstraße 21, 4031 Basel, Switzerland. ${ }^{2}$ Second

Department of Propedeutic Surgery, Athens University Medical School, Laiko General Hospital, 17 Agiou Thoma Street, 11527 Athens, Greece. ${ }^{3}$ First

Department of Pathology, School of Medicine, National University of Athens, Athens, Greece. ${ }^{4}$ First Department of Surgery, Athens University Medical

School, Laiko General Hospital, 17 Agiou Thoma Street, 11527 Athens,

Greece.
\end{abstract}

Published online: 24 February 2021

\section{Reference}

1. Tampakis A, Tampaki E, Nonni A, et al. High fascin-1 expression in colorectal cancer identifies patients at high risk for early disease recurrence and associated mortality. BMC Cancer. 2021;21:153. https://doi.org/10.1186/s12 885-021-07842-4.

The original article can be found online at https://doi.org/10.1186/s12885021-07842-4.

*Correspondence: Athanasios.Tampakis@usb.ch

${ }^{+}$Athanasios Tampakis and Ekaterini-Christina Tampaki contributed equally to this work.

'Clarunis, University Center for Gastrointestinal and Liver Disorders, University Hospital of Basel, Spitalstraße 21, 4031 Basel, Switzerland

${ }^{2}$ Second Department of Propedeutic Surgery, Athens University Medical School, Laiko General Hospital, 17 Agiou Thoma Street, 11527 Athens, Greece Full list of author information is available at the end of the article

C C The Author(s). 2021 Open Access This article is licensed under a Creative Commons Attribution 4.0 International License, which permits use, sharing, adaptation, distribution and reproduction in any medium or format, as long as you give appropriate credit to the original author(s) and the source, provide a link to the Creative Commons licence, and indicate if changes were made. The images or other third party material in this article are included in the article's Creative Commons licence, unless indicated otherwise in a credit line to the material. If material is not included in the article's Creative Commons licence and your intended use is not permitted by statutory regulation or exceeds the permitted use, you will need to obtain permission directly from the copyright holder. To view a copy of this licence, visit http://creativecommons.org/licenses/by/4.0/ The Creative Commons Public Domain Dedication waiver (http://creativecommons.org/publicdomain/zero/1.0/) applies to the data made available in this article, unless otherwise stated in a credit line to the data. 